Acta Technologica Agriculturae 2

Nitra, Slovaca Universitas Agriculturae Nitriae, 2018, pp. 56-62

\title{
EVALUATION OF A GREENHOUSE UNDER TROPICAL CONDITIONS USING IRISH POTATO (SOLANUM TUBEROSUM) AS THE TEST CROP
}

\author{
Timothy Denen AKPENPUUN ${ }^{1 *}$, Yahaya MIJINYAWA ${ }^{2}$ \\ ${ }^{1}$ Agricultural and Biosystems Engineering, University of Ilorin, llorin, Nigeria \\ ${ }^{2}$ Agricultural and Environmental Engineering, University of Ibadan, Ibadan, Nigeria
}

\begin{abstract}
Irish potato is a tuberous staple food predominantly grown in Plateau State, a temperate climate. As a result of the high demand for Irish potato, there is a shortage in its supply in Nigeria. The shortage in its supply could be attributed to climate change and the fall in the production level. This study sought to establish the potential of a greenhouse (GH) for the production of Irish potato in the tropics. The experiments were carried out in the rainy and dry seasons of 2015/2016 and 2016/2017. Nicola, Diamant, Batita, New Seed and Okonkwo varieties of Irish potato were cultivated inside and outside the greenhouse. Thirty seedlings of each variety were planted using Completely Randomised Experimental Design. Greenhouse performance was evaluated in terms of air temperature, relative humidity, vapour pressure deficit, yield, stem diameter, stem height and dry matter content. The result of the analysis of variance revealed that the mean greenhouse and open-field temperature, relative humidity and vapour pressure deficit differed significantly at 0.01 during the rainy and dry season. The yield and growth data in and outside the greenhouse were significantly different at 0.01 . Diamant, Batista and Okonkwo varieties are recommended for GH production.
\end{abstract}

Keywords: greenhouse; Irish potato; temperature; climate; tropical climate; open field; yield; greenhouse; experiments

Controlled Environment Agriculture (CEA) is an integrated science and engineering-based approach that provides favourable environmental conditions for crop production while optimising resources such as land, capital, labour, equipment, water and energy (Kacira, 2012). It is utilised to protect crops from harsh climatic conditions and pests, and also to create a suitable indoor microclimate that facilitates optimal crop production. A greenhouse is constructed in order to achieve a controlled environment in agricultural practice. This is achieved by appropriate construction of greenhouses and installation of equipment to monitor and control air temperature, relative humidity, vapour pressure deficit and light levels in the greenhouse (Ingeli et al., 2015). Greenhouses are intensively used for protection of tender or out-of-season plants from excessive heat or cold in countries such as Israel, United States of America, Australia, India and Turkey. Greenhouses are often used for the cultivation of horticultural crops, vegetables, fruits and flowers. Greenhouses are also used to protect research and isolate plants from diseases or insects (Mijinyawa and Osiade, 2011; Both et al., 2015). Despite the great potential of greenhouses in enhancing the agricultural productivity, they are currently sparingly used in many African countries, including Nigeria, because the prevailing ambient conditions are suitable for crop production (Lindley and Whitaker, 1996; Mijinyawa and Akpenpuun, 2015).

There has been a gradual increase in the advocacy for commercial greenhouse crop production in the sub-tropical and tropical regions such as Africa and Asia. The rise in advocacy could be attributed to the effect of climate change, which is already manifesting in crop failures and livestock death resulting in high economic losses, contributing to high food prices and counteracting food security. It has been predicted that if mitigation measures are not put in place before 2020, the crop yield of the preponderantly rain-fed African agriculture would drop by $50 \%$ (Unanaonwi, 2014; Mijinyawa and Osiade, 2011). Hitherto, Nigerian farmers could predict the onset and duration of seasons. On the basis of such a prediction, Nigerian farmers could plan their agricultural calendar, but in recent years, their predictions have failed because of climate change. This change in climate has negatively affected the fortunes of all categories of farmers. Other factors necessitating the introduction of greenhouse agriculture are increasing demand for agricultural produce and the rising standard of living (Mijinyawa and Akpenpuun, 2011).

Irish potato is a starchy tuberous crop from Solanum tuberosum of the Solanaceae family, cultivated for food and as an industrial raw material. Irish potato is a highly cherished food crop worldwide, but its cultivation is limited to certain areas by climatic requirements. This has made Irish potato a major source of income for farmers in such areas where it can be cultivated. The crop was introduced into Nigeria in the early $20^{\text {th }}$ century by European miners in Jos, Plateau State. The planting stock was obtained from Ireland, hence the name Irish potato (Jwanya et al., 2014b). Irish potato is the most fruitful and efficient tuber crop in terms of tuber yield and maturity period. Irish potato has a short growing cycle 
of 60 to 90 days, giving it the advantage of being cultivated two to three times a year, as opposed to 270 and 360 days for yam and cassava respectively, which are cultivated once a year (Jwanya et al., 2014a). The possibility of multiple cultivations within a year has made Irish potato a potential crop that can relieve the pressure of food insecurity on the poor rural farmers and the larger society.

Irish potato is the fourth largest cultivated food crop in the world after wheat, rice, and maize (FAO, 2014). It is an important source of food, income and employment in developing countries because of its high energy content and easy production (FAO, 2008). The world production of Irish potato in 2013 was 368 million tonnes, with Nigeria contributing 1,200,000 tonnes. At this level of production, Nigeria is the fourth largest producer of Irish potato in SubSaharan Africa and it is the $41^{\text {st }}$ food production country in the world (World Bank Report, 2013). Jos Plateau accounts for about $95 \%$ of the total Irish potato produced in Nigeria (Zemba et al., 2013; Wuyep et al., 2013; Jwanya et al., 2014a). Other areas in Nigeria where Irish potato can possibly be cultivated during the cold harmattan periods from November to February include Obudu Highlands in Cross River State, Mambilla Plateau in Taraba State and Biu Plateau in Borno State (NRCRI, 2005; Okonkwo et al., 2009).

\section{Material and methods}

The greenhouse was evaluated using Irish potato as the test crop for the experiments, which were carried out in Ilorin during the rainy season of 2015 (August 2015 - October 2015) and dry seasons of 2015 and 2016 (December 2015 - March 2016). The greenhouse temperature, relative humidity, and vapour pressure deficit were the environmental parameters monitored and measured, while total yield, plant height, stem diameter and dry matter content were the crop parameters used in the evaluation of the greenhouse.

\section{Results and discussion}

\section{Environmental parameters}

Tables 1, 2 and 3 provide the descriptive statistics, analysis of variance and Tukey Honestly Significant Difference (HSD) test of the parameters. It was observed that the temperature in the greenhouse in the rainy and dry season were in the range of $21.4-24.7^{\circ} \mathrm{C}$ and $22.4-31.2^{\circ} \mathrm{C}$, respectively, while open-field temperature was in the range of $27-30.9^{\circ} \mathrm{C}$ and $34.2-40{ }^{\circ} \mathrm{C}$ in the rainy and dry season, respectively. The descriptive statistics, on the other hand, showed that the mean greenhouse and open-field temperature for experiment one were $23.6{ }^{\circ} \mathrm{C}$ and $28.9{ }^{\circ} \mathrm{C}$ respectively, while the mean greenhouse and open-field temperature for the dry season were $26.6^{\circ} \mathrm{C}$ and $36.9^{\circ} \mathrm{C}$, respectively. In addition, a narrow temperature difference of about $5-6{ }^{\circ} \mathrm{C}$ was observed between the greenhouse and the open-field environment during the rainy season. However, during the dry season, the temperature difference between the greenhouse and open-field was $9-12{ }^{\circ} \mathrm{C}$. This result was in line with the findings of Fatnassi et al. (2002) and Bailey et al. (2003), who investigated the greenhouse microclimate in the tropics and reported a temperature range of $10-12{ }^{\circ} \mathrm{C}$.

The relative humidity $(\mathrm{RH})$ in the rainy and dry season in the $\mathrm{GH}$ ranged between $75.6 \%$ and $92.0 \%$, and between $64.4 \%$ and $80.3 \%$, respectively; however, considering the open-field, it ranged between $79.3 \%$ and $91.6 \%$ and between $48.1 \%$ and $71.4 \%$ in the rainy and dry season, respectively. The descriptive statistics also showed that mean greenhouse relative humidity during the rainy and dry season were $83.4 \%$ and $74.8 \%$, respectively. A mean $\mathrm{RH}$ of $60.20 \%$ was recorded in the open-field during the dry season. The open-field $\mathrm{RH}$ was lower than the minimum value required for Irish potato production. A difference of $1.30 \%$ and $14.6 \%$ was recorded between the greenhouse and open-field $\mathrm{RH}$ in the rainy and dry season, respectively.

Table 1 Descriptive statistics of environmental parameters for the rainy and dry season

\begin{tabular}{|l||c|c|c|c|c|c|}
\hline Treatment & Experiment & Count & Sum & Mean & Standard deviation & Sample variance \\
\hline GH temp & rainy & 90 & $2,126.8$ & 23.6 & 0.99 & 0.98 \\
\hline Amb. temp & rainy & 90 & $2,602.9$ & 28.9 & 1.09 & 1.2 \\
\hline GH RH & rainy & 90 & $7,510.0$ & 83.4 & 3.38 & 11.27 \\
\hline Amb. RH & rainy & 90 & $7,618.5$ & 84.7 & 2.57 & 6.6 \\
\hline GH VPD & rainy & 90 & 43.73 & 0.48 & 0.11 & 0.01 \\
\hline Amb. VPD & rainy & 90 & 117.9 & 1.31 & 0.23 & 0.05 \\
\hline GH temp & dry & 90 & $2,401.9$ & 26.7 & 2.72 & 7.42 \\
\hline Amb. temp & dry & 90 & $3,327.3$ & 37.0 & 1.6 & 2.55 \\
\hline GH RH & dry & 90 & $6,730.9$ & 74.8 & 2.99 & 8.93 \\
\hline Amb. RH & dry & 90 & $5,416.9$ & 60.2 & 6.5 & 42.23 \\
\hline GH VPD & dry & 90 & 80.08 & 0.89 & 0.18 & 0.03 \\
\hline Amb. VPD & dry & 90 & 222.28 & 2.47 & 0.44 & 0.19 \\
\hline
\end{tabular}

$\mathrm{GH}$ - greenhouse; $\mathrm{RH}$ - relative humidity; VPD - vapour pressure deficit 
Table 2 ANOVA for greenhouse and open-field environmental parameters

\begin{tabular}{|c|c|c|c|}
\hline Combination & $\mathbf{F}_{\text {statistics }}$ & P-value & $\mathbf{F}_{\text {critical }}$ \\
\hline Greenhouse and open-field temperature for the rainy season & $1,158.79$ & 0.00 & 3.89 \\
\hline Greenhouse and open-field RH for the rainy season & 7.32 & 0.01 & 3.89 \\
\hline Greenhouse and open-field VPD for the rainy season & 911.78 & 0.00 & 3.89 \\
\hline Greenhouse and open-field temperature for the dry season & 954.50 & 0.00 & 3.89 \\
\hline Greenhouse and open-field RH for the dry season & 375.03 & 0.00 & 3.89 \\
\hline Greenhouse and open-field VPD for the dry season & $1,008.08$ & 0.00 & 3.89 \\
\hline
\end{tabular}

Table 3 Tukey HSD test result for greenhouse and open-field weather parameters

\begin{tabular}{|l||c|c|c|c|c|}
\hline \multirow{2}{*}{ Treatments pair } & Experiment & \multirow{2}{*}{$\begin{array}{c}\text { Tukey } \\
\text { HSD } \mathbf{Q}_{\text {statistic }}\end{array}$} & \multicolumn{2}{|c|}{ Tukey HSD $\mathbf{Q}_{\text {critical }}$} & \multirow{2}{*}{$\begin{array}{c}\text { Tukey HSD } \\
\text { inference }\end{array}$} \\
\cline { 3 - 6 } & & $\mathbf{0 . 0 1}$ & $\mathbf{0 . 0 5}$ & significant \\
\hline GH vs amb. temp. & rainy & 5.290 & 3.682 & 2.791 & significant \\
\hline GH vs amb RH & rainy & 3.827 & 3.682 & 2.791 & significant \\
\hline GH vs amb VPD & rainy & 42.616 & 3.682 & 2.791 & significant \\
\hline GH vs amb temp. & dry & 43.691 & 3.682 & 2.791 & significant \\
\hline GH vs amb RH & dry & 27.387 & 3.682 & 2.791 & significant \\
\hline GH vs amb VPD & dry & 44.934 & 3.682 & 2.791 & \\
\hline
\end{tabular}

The data also show that the vapour pressure deficit (VPD) in the rainy season was within the range of $0.23-0.79 \mathrm{kPa}$ and $0.61-1.19 \mathrm{kPa}$, while in the dry season, vapour pressure deficit was within the range of $0.79-1.65 \mathrm{kPa}$ and $1.75-$ $3.41 \mathrm{kPa}$. Mean greenhouse vapour pressure deficit during the first and dry season was 0.48 and $0.89 \mathrm{kPa}$, respectively. The VPD obtained in both open-field experiments exceeded the value of $1.0 \mathrm{kPa}$ observed in regions where Irish potato is cultivated, while the VPD in the greenhouse experiment was lower than $1.0 \mathrm{kPa}$. The $\mathrm{p}$-values of $p<0.00, p<0.01$, and $p<0.00$, and $p<0.00, p<0.00$, and $p<0.00$ at a significant level of $p<0.05$ corresponding to the F-statistic for the pairs of temperature, relative humidity, and vapour pressure deficit inside the $\mathrm{GH}$ and open-field (OP) in the two experiments were obtained.

The $p$-values obtained from the one-way analysis of variance were all lower than 0.05 , suggesting that the treatments were significantly different in both seasons. In order to further establish that the pairs of temperature, relative humidity and vapour pressure deficit significantly differed, Tukey HSD was performed on the data. The result of the posthoc test is presented in Table 3.

The critical Tukey HSD Q-statistics $\left(Q_{\text {critical }}\right)$ values for temperature, relative humidity and vapour pressure deficit obtained from the Studentized range distribution, based on the number of treatments $(k=2)$ and the degree of freedom $(v=178)$ at the significance levels $\alpha=0.01$ and $\alpha=0.05$, were 3.682 and 2.791, respectively. The observed Q-statistics were compared with the critical Q-statistics for all pairs of treatments and it showed that the values of the observed Q-statistics were higher than the values of the critical Q-statistics. The observed Q-statistics ranged between 3.827 and 44.934. These observations have shown that the means of all the environmental parameters were significantly different from each other in the two experiments.

\section{Irish potato yield}

Yield data was obtained from 150 samples of five varieties of Irish potato (Nicola, Diamant, Batita, Okonkwo, New Seed) from each of the two experiments. Table 4 shows the descriptive statistics of the yield data in terms of mean, standard deviation (SD) and sample variance obtained from each of the varieties from the rainy and dry seasons. According to the results, GHR_C1, GHR_D1, OPR_C1, and OPR_D1 had yield means of $30.8(S D=11.2), 35.5(S D=8.8)$, 30 ( $S D=12.2$ ) and $40.2(S D=10.2)$, respectively for the first ridge experiment. For the second ridge experiment, GHR_C2, GHR_D2, OPR_D2, and OPR_C2 had yield means of $47.3(\mathrm{SD}=7.9), 52.9(\mathrm{SD}=5.0), 15(\mathrm{SD}=1.60)$, and 4.1 $(S D=0.9)$, respectively.

The potato yield data was further subjected to a oneway analysis of variance. The result of ANOVA is presented in Table 5. The results presented in the ANOVA table show that the observed $\mathrm{F}$ distribution was 27.2 for the comparison of greenhouse and open-field ridge yield in the rainy season. In the comparison of the greenhouse and open-field ridge yield in the dry season, an $F$ distribution of 216.30 was obtained. These $F$ values exceeded the critical $F$, leading to a conclusion that there were significant differences in the yield means of the individual varieties of Irish potato. As a result, Tukey HSD comparison test was carried out to evaluate the pairwise differences among the varieties.

Figs 1 and 2 present the bar charts for the total yield per area for the greenhouse and open-field ridge for the rainy season and greenhouse and open-field ridge for the dry season. As shown in Fig. 1, GHR_D1 and OPR_D1 had the yield of $400 \mathrm{~g} \cdot \mathrm{m}^{-2}$ and $350 \mathrm{~g} \cdot \mathrm{m}^{-2}$ for the open-field and greenhouse ridge in the rainy season. Fig. 2 shows that GHR_D2, GHR_C2 and GHR_B2 had the yield of $522.2 \mathrm{~g} \cdot \mathrm{m}^{-2}$, $467.9 \mathrm{~g} \cdot \mathrm{m}^{-2}$ and $390.1 \mathrm{~g} \cdot \mathrm{m}^{-2}$, respectively. 
Table 4 Descriptive statistics of ridge potato yield for the rainy and dry season

\begin{tabular}{|c|c|c|c|c|c|}
\hline Groups & Count & Sum (g) & Mean (g) & Standard deviation & Sample variance \\
\hline GHR_A1 & 30 & 741 & 24.7 & 5.5 & 30.1 \\
\hline GHR_B1 & 30 & 848 & 28.3 & 7.8 & 61.2 \\
\hline GHR_C1 & 30 & 924 & 30.8 & 11.2 & 124.4 \\
\hline GHR_D1 & 30 & 1,064 & 35.5 & 8.8 & 76.9 \\
\hline GHR_E1 & 30 & 510 & 17.0 & 3.5 & 12.4 \\
\hline OPR_A1 & 30 & 672 & 22.4 & 5.5 & 29.9 \\
\hline OPR_B1 & 30 & 958 & 31.9 & 9.9 & 98.2 \\
\hline OPR_C1 & 30 & 900 & 30 & 12.2 & 149.7 \\
\hline OPR_D1 & 30 & 1,214 & 40.2 & 10.2 & 104.0 \\
\hline OPR_E1 & 30 & 731 & 24.4 & 5.3 & 28.4 \\
\hline GHR_A2 & 30 & 720 & 24.0 & 7.1 & 50.6 \\
\hline GHR_B2 & 30 & 1,184 & 39.5 & 12.0 & 144.2 \\
\hline GHR_C2 & 30 & 1,420 & 47.3 & 7.9 & 62.3 \\
\hline GHR_D2 & 30 & 1,586 & 52.9 & 5.0 & 25.0 \\
\hline GHR_E2 & 30 & 805 & 26.8 & 7.0 & 49.6 \\
\hline OPR_A2 & 30 & 65 & 2.2 & 0.8 & 0.7 \\
\hline OPR_B2 & 30 & 50 & 1.7 & 0.8 & 0.6 \\
\hline OPR_C2 & 30 & 124 & 4.1 & 0.9 & 0.9 \\
\hline OPR_D2 & 30 & 150 & 5.0 & 1.6 & 2.5 \\
\hline OPR_E2 & 30 & 80 & 2.7 & 1.2 & 1.4 \\
\hline
\end{tabular}

GHR - greenhouse ridge, OPR - open-field ridge; Nicola - A, Diamant - B, Batita - C, Okonkwo - D, New Seed - E

Table 5 ANOVA for greenhouse and open-field potato yield

\begin{tabular}{|c|c|c|c|}
\hline Combination & $\mathbf{F}_{\text {statistics }}$ & P-value & $\mathbf{F}_{\text {critical }}$ \\
\hline Greenhouse vs open-field ridge plant yield of rainy season & 27.2 & 0.00 & 1.91 \\
\hline Greenhouse vs open-field ridge plant yield of dry season & 216.30 & 0.00 & 1.91 \\
\hline
\end{tabular}

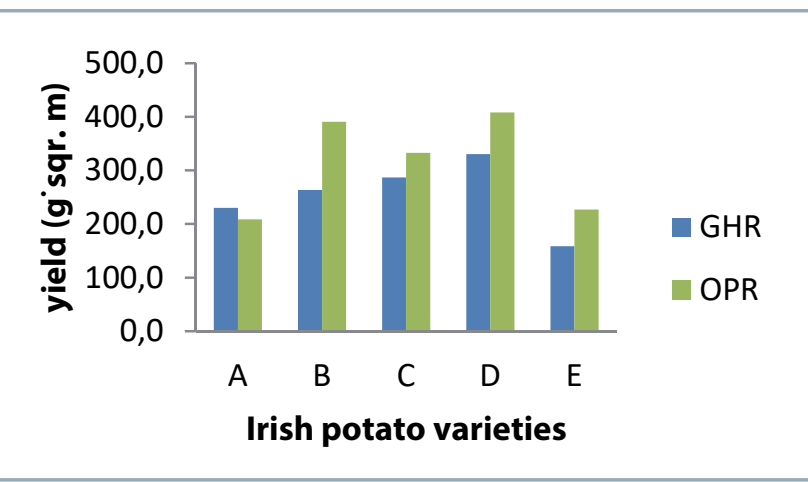

Fig. 1 Yield of ridge Irish potato experiment (the rainy season) GHR - greenhouse ridge, OPR - open field ridge; A - Nicola, B - Diamant, C - Batita, D - Okonkwo, E - New Seed

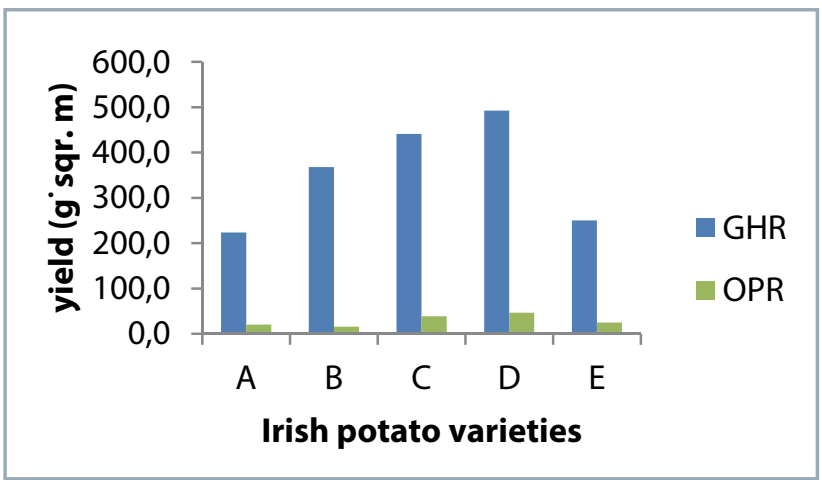

Fig. 2 Yield of ridge Irish potato experiment (the dry season) GHR - greenhouse ridge, OPR - open field ridge; A - Nicola, B - Diamant, C - Batita, D - Okonkwo, E - New Seed 
Table 6 Greenhouse and open-field ridge yield Tukey HSD results

\begin{tabular}{|c|c|c|c|c|c|c|}
\hline \multirow[t]{2}{*}{ Treatments pair } & \multirow{2}{*}{$\begin{array}{l}\text { Tukey HSD } \\
\text { Q-statistic, the } \\
\text { rainy season }\end{array}$} & \multirow{2}{*}{$\begin{array}{l}\text { Tukey HSD } \\
\text { inference, the } \\
\text { rainy season }\end{array}$} & \multicolumn{2}{|c|}{$\mathbf{Q}_{\text {critical }}$} & \multirow{2}{*}{$\begin{array}{l}\text { Tukey HSD } \\
\text { Q-statistic, the } \\
\text { dry season }\end{array}$} & \multirow{2}{*}{$\begin{array}{c}\text { Tukey HSD } \\
\text { inference, the } \\
\text { dry season }\end{array}$} \\
\hline & & & 0.01 & 0.05 & & \\
\hline GHR_A vs OPR_A & 1.489 & insignificant & 5.215 & 4.509 & 20.579 & ${ }^{* *} p<0.01$ \\
\hline GHR_B vs OPR_B & 2.373 & insignificant & 5.215 & 4.509 & 35.629 & ${ }^{* *} p<0.01$ \\
\hline GHR_C vs OPR_C & 0.518 & insignificant & 5.215 & 4.509 & 40.719 & ${ }^{* *} p<0.01$ \\
\hline GHR_D vs OPR_D & 3.085 & insignificant & 5.215 & 4.509 & 45.117 & ${ }^{* *} p<0.01$ \\
\hline GHR_E vs OPR_E & 4.768 & ${ }^{*} p<0.05$ & 5.215 & 4.509 & 22.779 & ${ }^{* *} p<0.01$ \\
\hline
\end{tabular}

$\mathrm{GHR}$ - greenhouse ridge, OPR - open-field ridge

\section{Tukey HSD test result for yield}

The $p$-values corresponding to the F-statistic of one-way ANOVA carried out on the data for individual varieties and between them were lower than 0.01 and 0.05 , except for the open-field ridge plant yield in the dry season. This strongly suggested that one or more pairs of varieties were significantly different. Consequently, the Tukey HSD of multiple means comparisons was applied to each of 10 variety pairs of the yield from the greenhouse ridge and open-field ridge experiments to identify which of the pairs exhibited a statistically significant difference.

The critical values of the Tukey-Kramer HSD Q-statistic were obtained from the Studentized Range distribution table at the significance levels of 0.01 and 0.05 based on the number of treatments, $k(k=5)$ and degrees of freedom, $v(v=145)$. The Tukey HSD Q-statistic for each variety pair of the yield is presented in Table 6.

In the rainy season, only the comparison of the yield obtained from New Seed differ significantly at $p<0.05$. However, in the dry season, the yield from the greenhouse ridge experiment all differed significantly from the openfield ridge experiment at $p<0.01$ and $p<0.05$ significance levels.

\section{Growth index}

The vegetative growth of the Irish potato plants was first recorded 28 days after planting and subsequently once in every two weeks until the end of the experiments. Tables 7 and 8 present the analysis of variance data of stem height and diameter obtained in the rainy and dry season, respectively.

Irish potato stem height data obtained in the rainy season showed that both greenhouse ridge and open-field ridge potato height ranged between 300 and $600 \mathrm{~mm}$. In the dry season, greenhouse ridge potato height ranged between 200 and $600 \mathrm{~mm}$. However, open-field ridge potato height ranged between 50 and $300 \mathrm{~mm}$.

The descriptive statistics of the rainy season data showed that New Seed $(371.9 \mathrm{~mm}$ ) and Batita $(368.5 \mathrm{~mm}$ ) reached the highest height in the greenhouse, while Okonkwo $(378.3 \mathrm{~mm})$ and New Seed $(370.6 \mathrm{~mm})$ were highest in the open-field experiment. Considering the potted potato plants in the greenhouse, New Seed and Diamant showed 310.5 and $303.9 \mathrm{~mm}$ in height, respectively, while Nicola and Okonkwo showed 353.9 and $334.5 \mathrm{~mm}$, respectively. In the dry season, Nicola $(401.2 \mathrm{~mm})$ and Okonkwo $(392.9 \mathrm{~mm})$, and Nicola $(187.9 \mathrm{~mm})$ and Okonkwo $(177.3 \mathrm{~mm})$ were the highest specimens in greenhouse ridge and open-field ridge plants, respectively.

The stem height data was further analysed using the one-way analysis of variance and the results showing that the potato stem height in greenhouse ridge/open-field ridge (GHR/OPR) for both the rainy and dry season differed significantly, are presented in Table 7.

Another vegetative growth parameter - stem diameter was recorded during the experiments. Stems diameters of greenhouse ridge and open-field ridge potato plants ranged between 20 and $39 \mathrm{~mm}$ in the rainy season, while in the dry season, greenhouse ridge stem diameter ranged

Table 7 ANOVA for greenhouse and open-field plant height

\begin{tabular}{|l|c|c|c|}
\hline Combination & F $_{\text {statistics }}$ & P-value & $\mathbf{F}_{\text {critical }}$ \\
\hline Greenhouse vs. open-field ridge plants height of rainy & 2.25 & 0.03 & 1.99 \\
\hline Greenhouse vs. open-field ridge plant height of dry & 29.62 & $p<0.01$ & 1.99 \\
\hline
\end{tabular}

Table 8 ANOVA for greenhouse and open-field plant stem diameter

\begin{tabular}{|c|c|c|c|}
\hline Combination & $\mathbf{F}_{\text {statistics }}$ & P-value & $\mathbf{F}_{\text {critical }}$ \\
\hline Greenhouse vs open-field ridge plants stem diameter rainy & 12.15 & $p<0.01$ & 1.99 \\
\hline Greenhouse vs open-field pot plants stem diameter rainy & 2.99 & $p<0.01$ & 2.12 \\
\hline Greenhouse vs open-field ridge plant stem diameter of dry & 3.98 & $p<0.0$ & 1.99 \\
\hline Greenhouse vs open-field pot plant stem diameter of dry & 5.18 & $p<0.01$ & 2.12 \\
\hline
\end{tabular}




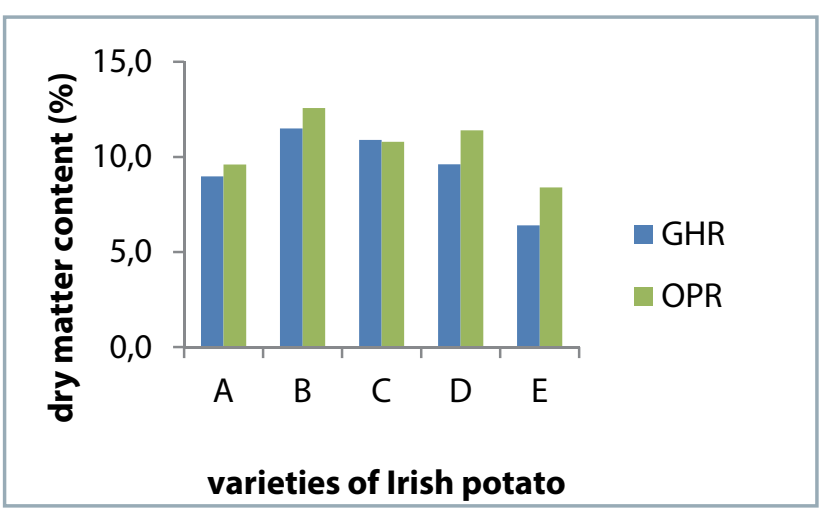

Fig. 3 Dry matter content of Irish potato (the rainy season)

from 14 to $27 \mathrm{~mm}$ and open-field ridge potato plant stems diameter ranged from 20 to $37 \mathrm{~mm}$.

The descriptive statistics of the stem diameter data showed that the mean of the potato stem diameter obtained in the greenhouse ridge plants from the rainy and dry season ranged between 29 and $30 \mathrm{~mm}$ and between 18 and $21 \mathrm{~mm}$, respectively. Considering the open-field ridge plants, it ranged between 21 and $23 \mathrm{~mm}$ and between 21 and $25 \mathrm{~mm}$ in the rainy and dry season, respectively. The analysis of variance of the stem diameter in Table 8 shows that the comparison between greenhouse $(\mathrm{GH})$ and open-field (OP) ridge potato stem diameter all differed significantly at $p<0.05$.

The analysis of variance of the stem diameter shows that the comparison between $\mathrm{GH}$ and OP potato stem diameter differed significantly in all cases at $p<0.05$.

Figures 3 and 4 present the dry matter content of the yield obtained from the rainy and dry season, respectively. As shown in the figures, Diamant (11.5\%) and Batita (10.9\%) varieties had the highest dry matter content in the greenhouse ridge experiment in the rainy season. Likewise, Batita (12.67\%) and Okonkwo (11.4\%) also had the highest dry matter content in the open-field ridge experiment in the rainy season. The dry matter content of the yield in the rainy season all fell below the standard range of $14-20 \%$ from healthy potato tubers. However, as shown in Fig. 4, the entire yields obtained from greenhouse ridge (GHR) in the dry season were all above the standard range. However, only Batita obtained from open-field ridge (OPR_C) produced dry matter content $15.5 \%$, which was above the least $14 \%$ of the standard.

\section{Conclusion}

The main findings of this study include the evaluation of some critical points on how to appropriately manage microclimate in the greenhouse located in the tropics so that it would be favourable for growing Irish potato considering several major constraints, such as extremely high air temperature and low humidity.

The comparison of the environmental parameters recorded in the greenhouse and open-field environments and yield, stem diameter and stem height obtained from the five varieties of Irish potato showed that the greenhouse regulated the microenvironment during all the seasons. This research has shown that with appropriate managing

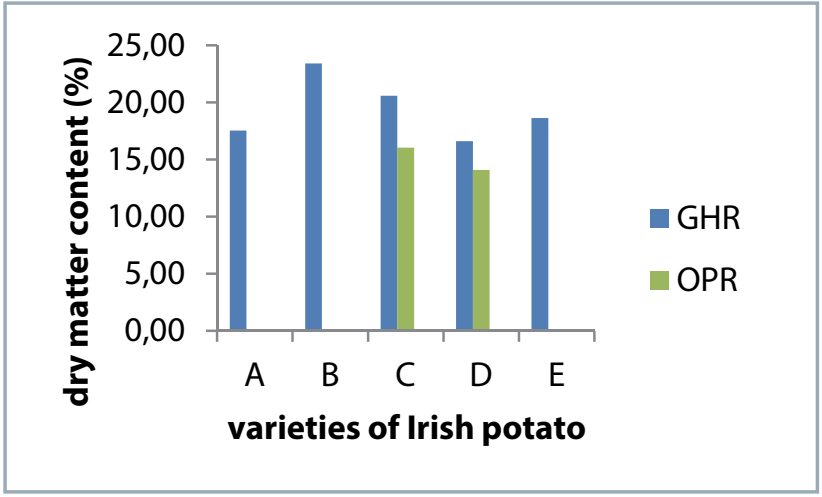

Fig. 4 Dry matter content of Irish potato (the dry season)

techniques, the microclimate in the greenhouse located in the tropics can be regulated to suit the production of Irish potato regardless of the harsh open-field environment experienced in llorin. However, in the dry season, more energy is needed to effectively and efficiently regulate the environment.

This research has identified three out of the five varieties of Irish potato that have the potential to be cultivated in the greenhouse in llorin environment and these varieties are Diamant (B), Batita (C) and Okonkwo (D).

This research has also established that:

1. The greenhouse production of Irish potato in a tropical climate of Ilorin is feasible in both rainy and dry seasons.

2. The split-gable design of greenhouse is appropriate for the tropical climate experienced in llorin.

3. Diamant (B), Batista (C) and Okonkwo (D) are the Irish potato varieties that have been identified to have the potential of being produced in a splitgable greenhouse in the climate of llorin.

\section{References}

BOTH, A. J. - BENJAMIN, L. - FRANKLIN, J. - HOLROYD, G. - INCOLL, L. D. - LEFSRUD, M. G. - PITKIN, G. 2015. Guidelines for measuring and reporting environmental parameters for experiments in greenhouses. In Plant Methods, vol. 11, no. 43. Available at: DOI 10.1186/s13007-015-0083-5.

BAILEY, B. J. - MONTERO, J. I. - PEREZ PARRA, J. - ROBERTSON, A. P. - BAEZA, E. -KAMARUDDIN, R. 2003. Airflow resistance of greenhouse ventilators with and without insect screens. In Biosystems Engineering, vol. 86, no. 2, pp. 217-229.

FATNASSI, H. - BOULARD, T. - DEMRATI, H. - BOUIRDEN, L. - SAPPE, G. 2002. Ventilation performance of a large Canarian-type greenhouse equipped with insect-proof nets. In Biosystems Engineering, vol. 81 , no. 1, pp. 97-105.

FAO. 2008. FAO Statistical Yearbook 2008. Rome, Italy : Food and Agricultural Organization.

FAO. 2014. FAO Statistical Yearbook 2014. Rome, Italy : Food and Agricultural Organization.

JWANYA, B. A. - DAWANG, N. C. - ZARMAI, D. U. - MASHAT, I. M. 2014a. Economic analysis of irrigated Irish potato production in Plateau State. In Developing Country Studies, vol. 4, no. 12, pp. 80-86. 
JWANYA, B. A. - DAWANG, N. C. - MASHAT, I. M. - GOIJING, B. S. 2014b. Technical efficiency of rain-fed Irish potato farmers in Plateau State, Nigeria: A stochastic frontier approach. In Developing Country Studies, vol. 4, no. 22, pp. 40-47.

KACIRA, M. 2012. Engineering CEA systems for a sustainable future: Status, challenges, and opportunities. In The Japan-America Frontiers of Engineering (JAFOE) Conference, Irvine, CA, USA. Available at: http://goo.gl/uqyaax.

LINDLEY, J. A. - WHITAKER, J. H. 1996. Agricultural Buildings and Structures. St Joseph Michigan : American Society of Agricultural Engineers.

INGELI, M. - GALAMBOŠOVÁ, J. - MACÁK, M. - RATAJ, V. 2015. Study on correlation of data from yield monitoring system and hand samples. In Acta Technologica Agriculturae, vol. 18, no. 1, pp. 10-13. MIJINYAWA, Y. - OSIADE, G. I. 2011. The status of greenhouses utilization in Oyo State, Nigeria. In Journal of Emerging Trends in Engineering and Applied Sciences (JETEAS), vol. 2, no. 4, pp. 561-566.

MIJINYAWA Y. - AKPENPUUN, T. D. 2015. Climate change effect on grain crops yields in Kwara State, Nigeria. In Proceedings of the $16^{\text {th }}$ International Conference and $36^{\text {th }}$ Annual General Meeting of the Nigerian Institution Agricultural Engineers. H. E. Igbadun, A. O. Lawal and Is'mail, H. (eds), pp. 104-111. The Nigerian Institution Agricultural Engineers (NIAE). Available at: www.niae.net.

MIJINYAWA, Y. - AKPENPUUN, T. D. 2011. Development of a glasshouse roof cleaner. In Journal of Agricultural Engineering and Technology (JAET), vol. 19, no. 2, pp. 29-38.

NATIONAL ROOT CROPS RESEARCH INSTITUTE (NRCRI). 2005. Research Highlights of the NRCRI, Umudike. Available at: www. nrcri.org/pages/ipotato.htm.
OKONKWO, J. C. - ENE, L. S. D. - OKOLI, O. O. 1995. Potato Production in Nigeria. National Root Crops Research Institute: Umudike, Umahia, Abia State, Nigeria, pp. 109.

OKONKWO, J. C. - AMADI, C. O. - NWOSU, K. I. 2009. Potato Production, Storage, Processing and Utilization in Nigeria. National Root Crops Research Institute: Umudike, Nigeria.

UNANAONWI, O. E. 2014. The effects of climate change on food production. In Research Journal of Agriculture and Environmental Management, vol. 3, no. 11, pp. 538-541.

WIEBE, K. 2003. Land quality, agricultural productivity, and food security at local, regional, and global scales. Paper presented at the American Agricultural Economics Association Annual Meeting, Montreal, Canada, July 27-30, 2003, Economic Research Service, USDA.

WORLD BANK REPORT. 2013. Getting Agriculture Growing in Nigeria: Framework for a National Growth Strategy. Washington D. C.

WUYEP, S. Z. - ZEMBA, A. A. - JAHKNWA, C. J. 2013. Effects of precipitation effectiveness on the yield of Irish potato (Solanum tuberosum) in Jos-Plateau, Nigeria. In International Journal of Research in Applied, Natural and Social Sciences, vol. 1, no., 5, pp. 27-32.

ZEMBA, A. A. - WUYEP, S. Z. - ADEBAYO, A. A. - JAHKNWA, C. J. 2013. Growth and yield response of Irish potato to climate in Jos-South, Plateau State, Nigeria. In Global Journal of Human Social Science, vol. 13 , no. 5 , pp. $43-52$. 